\title{
Technical and Experimental Study of the Solar Dehydration of the Moringa Leaf and Its Potential Integration to the Sustainable Agricultural Industry
}

\author{
Castillo T. Margarita ${ }^{1}$, Castillo T. Beatriz ${ }^{2}$, Miranda M. Erika Viviana ${ }^{3}$, Ovando S. \\ Juan Carlos $^{1}$
}

\begin{abstract}
Energy saving and environmental impact are two elements that must be considered in any sustainable process or proposal aimed at economic, social and cultural development. Moringa is a plant that has generated great interest in recent years due to its medicinal properties attributed, its leaves are an important source of food due to its high nutritional value. The plant is also used in traditional kitchens and medicinal remedies in various regions of the world. This work presents the characteristics of the dehydration of Moringa leaves using a solar dryer type greenhouse, open sun and electric oven. The tests were carried out at the Facultad de Ingeniería of the Universidad Autónoma de Campeche, in Campeche, México, located at 1951'00" north latitude and 90³1'59" west longitude, with a warm-humid climate, average values of solar irradiation of $980 \mathrm{~W} / \mathrm{m} 2$. The best drying time was obtained in the greenhouse dryer, reaching up to $59{ }^{\circ} \mathrm{C}$ inside the drying chamber and with average drying times of 4 hours. The percentage of moisture in fresh and dry moringa leaves on average was measured at 82.29 and 4.09, respectively. The results show the technical feasibility of the solar drying of the moringa leaf guaranteeing a final product of quality and an important energy economy.
\end{abstract}

Keywords: Solar drying, Debydration of moringa leaf, greenhouse solar dryer, drying chamber, solar drying kinetics

\section{Introduction}

Moringa (Moringa oleifera) are grown largely in tropical and sub-tropical areas (M.A. Ali, et. al, 2014) is a plant that has generated great interest in recent years because of its attributed medicinal properties (Cuellar, et. al., 2018). Moringa leaves and pods are an important source for food industries due to their high nutrient value: bread (Islamiyat Folashade Bolarinwa, et. al, 2017), cake (Kolawole et. al, 2013), yogurth (Heckman, et. al, 2015), soups (Babayeju, et. al, 2014), and many more applications in the kitchen around the world. In addition, it is known to use the plant in traditional cuisines and medicinal remedies in several regions of the world. Analytical studies have identified M. oleifera as an important source of essential nutrients; rich in protein, essential amino acids, minerals, and vitamins, with a relatively low amount of antinutrients (Falowo, et. al, 2018). There is evidence that the Moringa tree is ideal for the bioenergy industry

\footnotetext{
| ${ }^{1}$ Facultad de Ingeniería, Universidad Autónoma de Campeche, Campus V, predio s/n por Av Humberto Lanz Cárdenas y Unidad Habitacional Ecológica ambiental, Col. Ex Hacienda Kalá, C.P. 24085, San Francisco de Campeche, Campeche, México

$\mid{ }^{2}$ Centro Universitario Del Norte. Carretera Federal No. 23, Km. 191, C.P. 46200, Colotlán, Jalisco, México

| ${ }^{3}$ Universidad Autónoma de Guadalajara-Campus Tabasco. Prol. Paseo Usumacinta km 3.5 Fracc. El Country, Villahermosa, Tabasco, México
} 
products is evidenced, namely for bioethanol, biogas and biodiesel, given the lignocellulosic biomass content of these plants and characteristics of moringa seed oil (Kenthorai, et. al, 2017). Contains more than 90 nutrients, different antioxidants and all the eight essential amino acids (Fuglie, 2006).

\subsection{Solar Drying}

Solar energy has an enomous potential for diferent applications since it is easily accesible, abundant for the conuntries particulary located in tropical and subtropical regions, Solar energy has a huge potential for different applications, since it is easily accessible, abundant for countries particularly located in tropical and subtropical regions, is a sustainable source of energy (Pangavhane, D. R., et al, 2002). Solar energy is a good alternative for dehydrating food because it can supply the energy needed to evaporate water from food, fruits and plants, thus achieving an effective method of conservation. The application of dehydration techniques by solar drying is currently very widespread and there are different types, designs and modes of operations, of solar dryers with which it seeks to reduce drying times and costs, for example, indirect forced convection (Bahloul N. et al, 2009), Greenhouse solar dryers (Abdullah K, 1997), Indirect natural convection solar dryer with chimney, solar dryer with greenhouse as collector, solar tunnel dryer (air collector), hybrid solar dryer assisted by evacuated tube collectors (Narendra Kumar Mahara, Piyush Nema, 2017).

\subsection{Solar Drying Moringa Leaves}

The drying of the moringa leaves is by direct exposure to the sun or in ovens. The drying kinetics was investigated at different oven drying temperatures $\left(40{ }^{\circ} \mathrm{C}, 50^{\circ} \mathrm{C}\right.$ and $60^{\circ} \mathrm{C}$ ) using an established drying mathematical model (M. A. Ali, et al, 2014); there is another study in which the author designed and construction an indirect solar dryer with forced convention for drying moringa leaves and presents the results of calculations of the design parameters (S.K. Amedorme, et. Al, 2013). In other paper, solar tunnel dryer of $10 \mathrm{~m}$ x $3 \mathrm{~m} \times 2 \mathrm{~m}$ size went fabricated and evaluated A maximum temperature of $46.5^{\circ} \mathrm{C}$ was recorded at $1 \mathrm{pm}$ inside the solar tunnel dryer and at the same time 32.2 ${ }^{\circ} \mathrm{C}$ temperatures was observed during open sun drying process (Divyesh Vaghela. Et. al, 2018). It is important to mention that in the international scientific literature there are very few published studies on the solar drying of moringa leaves.

\section{Experimental Study}

In this work, the process of drying the moringa leaf in a solar dryer type greenhouse, solar drying in open sun and in a conventional non-convective dryer with electric heating at controlled temperature in a range between $45^{\circ} \mathrm{C}$ and $55^{\circ} \mathrm{C}$ is analyzed experimentally with the objective of determining the optimal drying process conditions and comparing conventional, traditional and solar, evaluating the possibility of integrating solar drying into sustainable Mexican agriculture.

\subsection{Materials and Methods}

Raw material. Mature moringa plants, grown in Campeche, Mexico, were 
selected. The branches were cut, and the leaves were separated and selected to obtain a homogeneous group, based on maturity, color, freshness and size. They were washed and weighed, the width, length and thickness were measured.

Experimental methods. Solar drying Technologies. Two solar drying technologies were selected: direct drying (open sun) and greenhouse dryer.

Open sun drying. In this process, moringa leaves are placed over an appropriate piece of plastic without overlaying them and left until sunset. If the leaves are not completely dry, they are collected and stored indoors. This process is repeated day after day until the drying process is complete.

Greenhouse dryer. Consists mainly of the coupling of a system of solar water heaters and

photovoltaic panels to a solar dryer type greenhouse. The first system coupled to the dryer consists of water heating through flat solar collectors of selective surface, the system is formed by the arrangement of 3 pieces, located two in series and one in parallel. This type of collector captures the solar radiation and heats the water reaching temperatures above of $80^{\circ} \mathrm{C}$, directing it to a heat exchanger that drives the hot air into the interior of the drying chamber, the hot air is driven by a $1 / 3 \mathrm{hp}$ fan and 2 turbines; getting dehydrated. The product contained in the drying chamber even during the night. The solar heaters are integrated by a $1 / 6$ hp pump, which manages a flow rate of $10 \mathrm{l} / \mathrm{s}$, in addition, consists of a hot water tank of up to 150 liters of water storage.

The air circulates inside the dryer in order to eliminate the evaporated humidity of the product, which is achieved by means of forced circulation, that is, the air is moved by a fan that consumes electrical energy. Using this type of circulation, speeds of air between 5 and $7 \mathrm{~m} / \mathrm{s}$. Both the water pumping system and the ventilation system are powered by panels photovoltaic Three photovoltaic panels of $130 \mathrm{~W}$ each and an inverter of $700 \mathrm{~W}$ are installed. $30 \mathrm{~A}$ charge controller and 4 storage batteries. Figure 1 shows the greenhouse solar dryer.
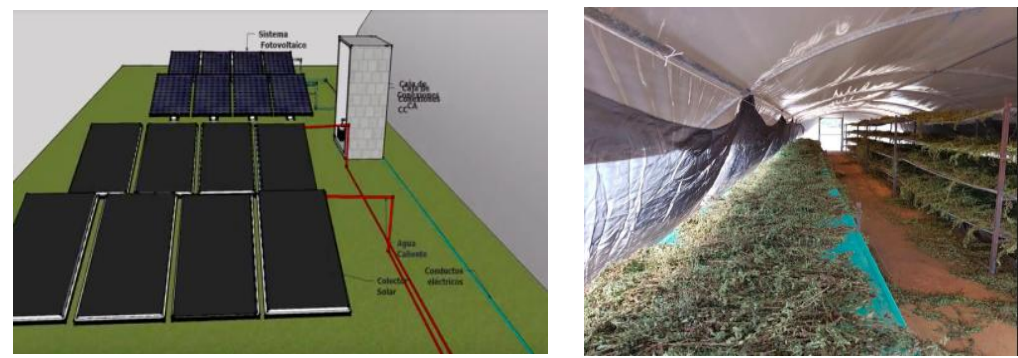

Figure 1. Solar system coupled to the solar dryer type greenhouse

Non-convective electric dryer. To obtain the drying kinetics, a Riossa electric oven without air convection was used. The weight loss was recorded by software and the drying temperatures were varied by $45^{\circ} \mathrm{C}$ and $55^{\circ} \mathrm{C}$.

\subsection{Instrumentation}

Humidity. A moisture analyzer, Boeco BMA150, with an accuracy of $\pm 1 \mathrm{mg}$ 
$(0.001 \%)$ was used to determine the humidity of the leaves. The leaf sample of approximately $1.5 \mathrm{~g}$ and was cut and placed in the analyzer. This procedure was performed for each condition before and after the drying process.

Water activity (aw). Water activity is a parameter that determines the stability of the food with respect to the ambient humidity. It was measured for both fresh and dried leaves before and after the drying process using portable water activity meter, Rotronic HygroPalm, with an accuracy of $\pm 0.01 \% \mathrm{mg}$. The mean of three measurements was reported at a room temperature of $24.5 \pm 1{ }^{\circ} \mathrm{C}$.

Temperature. The temperature and humidity inside the drying chambers were measured using a thermo-hygrometer Brannan with temperature and relative humidity accuracy of $\pm 1{ }^{\circ} \mathrm{C}$ and $\pm 3 \%$, respectively.

Weight. The weight of the samples was measured using a Boeco balance, model BPS40plus, with an accuracy of $\pm 0.001 \mathrm{~g}$.

Climatic parameters. During the test period, the weather parameters, including the temperature, humidity, air velocity, and global solar irradiance, were recorded. The specifications of the measuring instruments used in the experiments (manufacturer's data) are listed in Table 1.

Table 1. Specifications and description of measuring instruments from the weather station.

\begin{tabular}{|l|l|l|l|}
\hline VARIABLE & DESCRIPTION & MODEL & ACCURACY \\
\hline Global solar irradiance & LI-COR Pyranometer & LI-200R & $\begin{array}{l}\text { Azimuth: }< \pm 1 \% \text { on } 360^{\circ} \\
\text { to } 45^{\circ} \text { of elevation }\end{array}$ \\
\hline Relative humidity & NRG Systems & RH-5X & $\pm 3 \%$ \\
\hline Ambient temperature & NRG Systems & $110 \mathrm{~S}$ & $\pm 1.1^{\circ} \mathrm{C}$ \\
\hline Wind velocity and direction & $\begin{array}{l}\text { NRG Systems } \\
\text { Wind sensor }\end{array}$ & $\begin{array}{l}\text { Series \#200P } \\
\text { P2546C-OPR }\end{array}$ & $\begin{array}{l} \pm 3^{\circ} \\
\pm 0.3 \mathrm{~m} / \mathrm{s}\end{array}$ \\
\hline
\end{tabular}

\section{Results and Discussion}

The initial and final humidity and water activity values of the fresh and dried leaves are listed in Table 2 for each convection mode, including open sun and indirect solar dryer.

Table 2. Initial and final humidity and water activity obtained by different drying methods (average).

\begin{tabular}{lcccc} 
Drying operation & \multicolumn{2}{c}{$\begin{array}{c}\text { Humidity (\%) } \\
\text { mode }\end{array}$} & \multicolumn{2}{c}{ Water activity (aw) } \\
Initial & Final & Initial & Final \\
Electric oven $\left(45^{\circ} \mathrm{C}\right.$ and $\left.55^{\circ} \mathrm{C}\right)$ Average & 82.36 & 4.01 & 0.84 & 0.18 \\
Open sun & 81.54 & 3.84 & 0.82 & 0.16 \\
Greenhouse solar dryer & 82.98 & 4.43 & 0.88 & 0.2
\end{tabular}

\subsection{Weather conditions}

Figure 2 shows the change in the weather parameters during the test period with three sunny days. As can be seen, a maximum solar global irradiance of $980 \mathrm{~W} / \mathrm{m}^{2}$ was achieved, with the average maximum values ranging between 850 and $980 \mathrm{~W} / \mathrm{m}^{2}$. The average ambient temperature they varied of $30^{\circ} \mathrm{C}$ y $36.3{ }^{\circ} \mathrm{C}$, whereas the average maximum ambient temperature was $38.2{ }^{\circ} \mathrm{C}$. On the other hand, the minimum $\mathrm{RH}$ 
ranged between $43 \%$ and $55 \%$, the minimum average on the test days ranged between $39 \%$ and $45 \%$.

\subsection{Solar drying kinetics}

Figure 2, the evolutions of the climatological parameters are presented during the tests of April 9. As can be observed, during the test days, the maximum global irradiance reached was $1000 \mathrm{~W} / \mathrm{m}^{2}$, the range of the maximum average values being between 950 and $990 \mathrm{~W} / \mathrm{m}^{2}$. The minimum values of the ambient temperature ranged between $22.0{ }^{\circ} \mathrm{C}$ and $27.69{ }^{\circ} \mathrm{C}$, while the average maximum values measured varied between $29.0^{\circ} \mathrm{C}$ and $33.29{ }^{\circ} \mathrm{C}$. Regarding relative humidity, the minimum percentages reached varied between $18.1 \%$ and $29 \%$, while the maximum values measured were between $32.65 \%$ and $50 \%$.

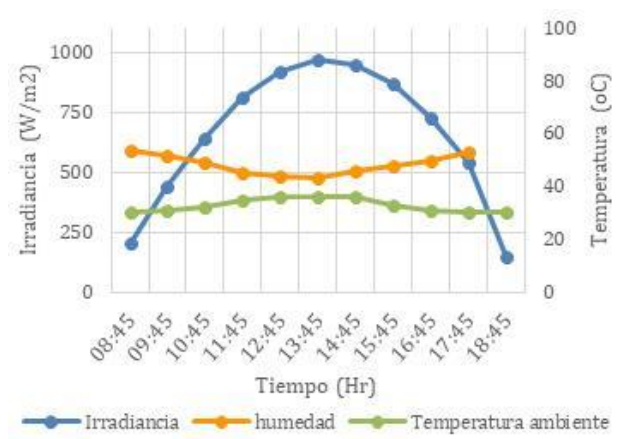

Figure 2. Solar irradiance, ambient temperature, and the relative bumidity the one day during test period

Figure 3 shows the change in the received solar irradiance of approximately $1000 \mathrm{~W} / \mathrm{m}^{2}$. The temperature variations inside the drying chambers were also measured, the internal temperature generally ranged between $40^{\circ} \mathrm{C}$ and $50^{\circ} \mathrm{C}$, with a maximum value of $60^{\circ} \mathrm{C}$. In the case of forced convection drying, the internal temperature generally ranged between 30 and $35^{\circ} \mathrm{C}$, with a maximum value of $40^{\circ} \mathrm{C}$. When the drying chamber was covered by shadow-mesh, the average temperatures ranged between $35^{\circ} \mathrm{C}$ and $40{ }^{\circ} \mathrm{C}$ with a maximum value of $43^{\circ} \mathrm{C}$.

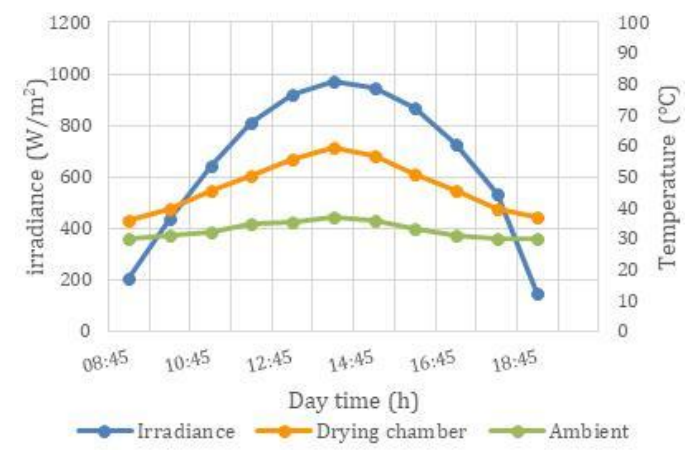

Figure 3. Variation in solar irradiance and temperature inside the drying chamber under greenhouse dryer 
Figure 4 shows the change in moisture content in greenhouse solar dryer and open sun. Faster drying kinetics was observed under greenhouse solar dryer, due to the high temperatures reached inside the dryer. The weight loss of the moringa leaves reached stability after drying for $150 \mathrm{~min}$ by exposure to sunlight.

A lower temperature was reached open sun because due to the direct exposure to the sun of the leaves of moringa they receive the effect that produces the convection of the ambient air. Thus, the drying kinetics was stabilized at $940 \mathrm{~min}$ in this case. The drying kinetics is too slow, in addition, the drying parameters such as heat input, moisture content, temperature, air flow rate of drying, can not be controlled. It is important to consider the low quality of the final product due to the environmental exposure of the product to dehydrate, however, it is an economical and very popular method (Midili A. et. al, 2001).

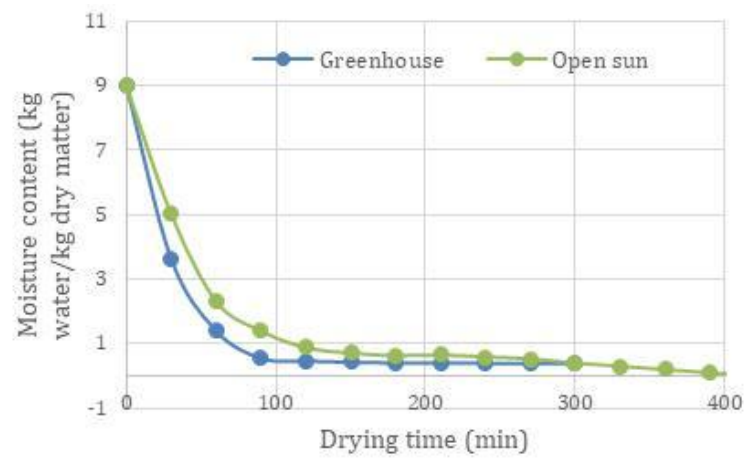

Figura 4. Variation in moisture content under open sun and greenhouse dryer

Figure 5 shows the drying rates as function of moisture content for each operation mode of the solar dryers. Constant drying rates were achieved when greenhouse solar dryer were used. The highest drying rate of $0.1800 \mathrm{~kg}$ water $/ \mathrm{kg}$ dry matter min, with an initial and final moisture content of 9 and $0.394 \mathrm{~kg}$ water $/ \mathrm{kg}$ dry matter. The drying rate obtained under open sun decreased very slowly to reach a $0.031 \mathrm{~kg}$ of water $/ \mathrm{kg}$ of dry matter min with a moisture content of $2.31 \mathrm{~kg}$ water $/ \mathrm{kg}$ dry matter.

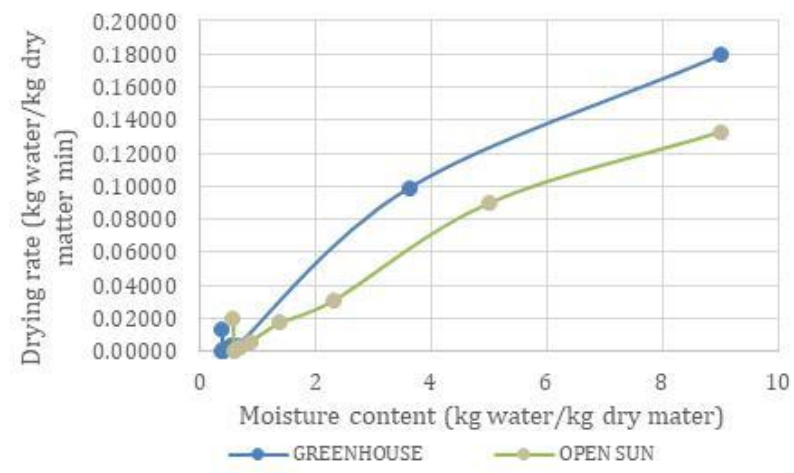

Figure 5. Drying rate as function of moisture content under under open sun and greenhouse dryer 


\subsection{Non convective drying at controlled temperatura}

The dehydration tests of the moringa leaves were carried out, obtaining the kinetics of drying at controlled temperatures of $45{ }^{\circ} \mathrm{C}$ and $55{ }^{\circ} \mathrm{C}$, three experiments being carried out for each of them. The dehydrated leaves had a final average weight of $0.664 \mathrm{~g}$ and in the oven $20 \mathrm{~g}$ were introduced.

Figure 6 represents the evolution of moisture in dry basis for the two established temperatures, with drying times of 400 minutes for a temperature of $55{ }^{\circ} \mathrm{C}$ and 840 minutes for $45^{\circ} \mathrm{C}$. Figure 7 shows the variations of the drying speed as a function of the moisture content for each of the set drying temperatures. At $55{ }^{\circ} \mathrm{C}$ the highest speeds were observed, two periods of almost constant decreasing speed were observed, which were presented in the moisture of 6.53 and 4.55 , on the other hand, at $45^{\circ} \mathrm{C}$ they were also observed Two periods of almost constant speed between the dry content moisture content intervals were: 8.15 and 5.02 .

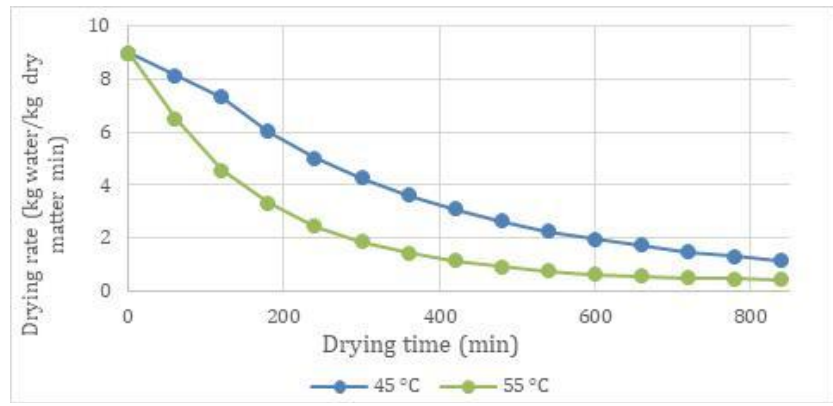

Figure 6. Variation of moisture content with respect to the drying time under controlled conditions at $45^{\circ} \mathrm{C}$ and $55^{\circ} \mathrm{C}$ in the electric dryer.

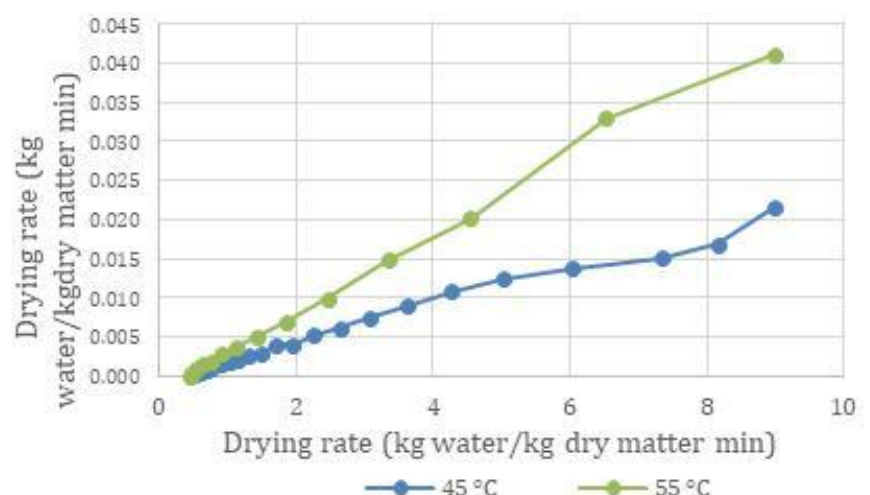

Figura 7. Variation of drying rate moisture with respect content under controlled conditions at $45^{\circ} \mathrm{C}$ and $55^{\circ} \mathrm{C}$ in the electric dryer.

It is important to mention that the data obtained in this experimental study agree with those obtained in a previous study in which the moringa leaf was dried at $40^{\circ} \mathrm{C}, 50^{\circ} \mathrm{C}$ and $60^{\circ} \mathrm{C}$, obtaining drying times of 8,5,75 and 2 hours, respectively (MA Ali, et al., 2014). 


\section{Conclusions}

The kinetics of drying under controlled conditions showed dehydration times of 8.5 and 6 hours on average, at $45^{\circ} \mathrm{C}$ and $55^{\circ} \mathrm{C}$, respectively; the optimum being $55^{\circ} \mathrm{C}$. The drying times obtained in the greenhouse solar dryer were shorter, $3 \mathrm{~h}$ and $15.6 \mathrm{~h}$ in the open, on average. The drying times in the greenhouse-type solar dryer were well below the best oven drying time $\left(55^{\circ} \mathrm{C}\right)$ and the color of the dehydrated leaves was retained according to the commercial ones.

The drying times in the open sky were very slow, it is a process that does not guarantee the final quality of the product and it is not possible to control the measurement parameters of the solar drying.

The experimental results carried out in this paper encourage the use of solar energy for the drying of agricultural products in Mexico by confirming the feasibility of using greenhouse dryers to dehydrate moringa leaves obtaining a significant energy economy, with little investment and with an acceptable quality of dehydrated product, also avoiding the use of conventional energy, minimizing environmental impacts.

\section{References}

M.A. Ali, Y.A. Yusof, N.L. Chin, M.N. Ibrahim, S.M:A. Basra. Drying kinetics and colour analysis of moringa oleifera leaves. Agriculture ans agricultural science procedia 2 (2014) 394-400.

M.L.Cuellar-Nuñeza, .Luzardo-Ocampo, R.Campos-Vega, M.A.Gallegos-Corona, E.González de Mejía, G.Loarca-Piña. Food Research International. Volume 105, March 2018, Pages 159-168

Islamiyat Folashade Bolarinwa, Tawakalitu Eniola Aruna, Akeem Olayemi Raji. Nutritive value and acceptability of bread fortified with moringa seed powder. Journal of the Saudi Society of Agricultural Sciences. Available online 6 May 2017. In Press, Corrected Proof

FL Kolawole, MA Balogun, DO Opaleke, HE Amali. An Evaluation of Nutritional and Sensory Qualities of Wheat -Moringa Cake. Agrosearch, Vol 13, No 1 (2013)

Hekmat, S., Morgan, K., Soltani, M., Gough, R. Sensory evaluation of locally-grown fruit purees and inulin fibre on probiotic yogurt in Mwanza, Tanzania and the microbial analysis of probiotic yogurt fortified with Moringa oleifera. Journal of Health, Population and Nutrition. Volume 33, Issue 1, 2015, Pages 60-67

Babayeju, A, Gbadebo, C., Obalowu, M., Otunola, G., Nmom, I., Kayode, R., Toye, A., Ojo, F. Comparison of Organoleptic properties of egusi and efo riro soup blends produced with moringa and spinach leaves. Food Sci. Qual. Manag. Volume 28, Pages 15-18

Andrew B.Falowo, Felicitas E. Mukumbo, Emrobowansan M. Idamokoroac José M. Lorenzo, Anthony J.Afolayan, Voster Muchenjea. Multi-functional application of Moringa oleiferaLam. In nutrition and animal food products: A review. Food Research International; Volume 106, April 2018, Pages $317-334$

Jegannathan Kenthorai, Raman Catarina M. Alves Edgard Gnansounou. A review on moringa tree and vetiver grass. Potential biorefinery feedstocks Bioresource Technology. Available online 31 October 2017. In Press, Corrected Proof

Fuglie, L.J., 2006. Combating Malnutrition with Moringa, The Miracle Tree: The Multiple Attributes of Moringa. Wageningen, The Netherlands CTA Publications 117-136.

Pangavhane, D. R., Sawhney, R. L. and Sarsavadia, P. N., Review of research and development work on solar drying. Energy conservation and management, 16 (2002) 45-61.

Neila Bahloul, Nourhène Boudhrioua, Mohammed Kouhila, Nabil Kechao. Convective solar drying of olive leaves. Food process engineering. 34 (2011) 1338-1362

Abdullah, K. Drying of vanilla pods using a greenhouse effect solar dryer. Food and agriculture organization of united nations. 1997. 
Divyesh Vaghela, Gajera Bhautik and S H Senga. Comparative study of solar tunnel and open sun drying for moringa oleifera leaves. International Journal of Science, Environment and Technology, Vol. 7, No 2, 2018, $472-476$

Narendra Kumar Mahara, Piyush Nema. Review on Solar Energy Dryer for Drying the Agricultural Products. International Journal for Scientific Research \& Development. 5 (2017) 2321-0613.

S.K. Amedorme1, J. Apodi and K. Agbezudor. Design and Construction of Forced Convection Indirect Solar Dryer for Drying Moringa Leaves. Sch. J. Eng. Tech., 3 (2013) 91-97.

Midilli A. Determination of pistachio drying behaviour and conditions in a solar drying systems. Int. J. Energy Res., 25 (2001) 715-25. 